\title{
Comparison of Infraclavicular and Supraclavicular Brachial Plexus Block in Upper Extremity Surgery
}

\author{
Üst Ekstremite Cerrahisinde İnfraklaviküler ve Supraklaviküler Brakiyal Pleksus \\ Bloğunun Karșılaștırılması
}

(D) Ayșe Gül Ferlengez, (1) Mustafa Tayfun Aldemir

Bezm-i Alem Vakıf Gureba Training and Research Hospital, Clinic of Anesthesiology and Reanimation, İstanbul, Turkey

\begin{abstract}
Introduction: In this study, we aimed to compare the efficacy of infraclavicular and supraclavicular brachial plexus block in patients undergoing upper extremity surgery.

Methods: After obtaining ethics committee approval, 50 patients who were between the ages of 18-80 years with an "American Society of Anesthesiologists (ASA)" score of I or II and who would undergo elective upper extremity surgery in the orthopedics and traumatology clinic were included in the study. Patients were randomly divided into two groups; 25 patients in infraclavicular block group (group I) and 25 patients in supraclavicular block group (group S). In both groups, nerves were searched using peripheral nerve stimulator and a total of $20 \mathrm{~mL}$ of $0.5 \%$ levobupivacaine and $20 \mathrm{~mL} 2 \%$ lidocaine were injected into the brachial plexus sheath. Demographic data, ASA scores, operative indications, time to block point, needle depth, onset of block time, operative time, duration of motor and sensory block, and onset of postoperative initial pain were recorded.
\end{abstract}

Results: There was no statistically significant difference regarding the demographic data and operative time between the patients. The time to block point, needle depth and onset of block time were significantly longer in group I than group $S$ $(p<0.001$, for all). No significant difference was found between the groups in terms of duration of motor block and sensory block, and onset of postoperative initial pain.

Conclusion: In our study, we found that the supraclavicular block is more advantageous in terms of time to block point, needle depth and onset of block time.

Keywords: Brachial plexus block, infraclavicular, regional anesthesia, supraclavicular

\section{ÖZ}

Amaç: Çalışmamızda üst ekstremite cerrahisi uygulanacak hastalara, infraklaviküler ve supraklaviküler bölgede brakiyal pleksus blokajı uygulamalarının etkinliğinin karşılaștırılmasını amaçladık.

Yöntemler: Hastanemiz etik kurul onayı alındıktan sonra ortopedi ve travmatoloji kliniğinde üst ekstremitesinden elektif olarak ameliyat olacak, "American Society of Anesthesiologists (ASA)" I-II aralığında, yașları 18-80 yıl arası 50 hasta çalıșmaya dahil edildi. Olgular infraklaviküler blok (grup i) ve supraklaviküler blok (grup S) olarak rastgele 25'er kişilik iki gruba ayrıldı. Grupların her ikisinde de periferik sinir stimülatörü yardımıyla ameliyat bölgesine göre iki ayrı sinir aranarak, toplamda $20 \mathrm{~mL} \% 0,5$ levobupivakain ve $20 \mathrm{~mL} \% 2$ lidokain brakiyal pleksus kılıf içerisine enjekte edildi. Hastaların demografik verileri, ASA skorları, ameliyat endikasyonları, blok noktasına ulaşma süreleri, iğne derinliği, blok başlama süresi, ameliyat süresi, motor ve duysal blok süresi ile ilk ağrı başlama süresi kaydedildi.

Bulgular: Olguların demografik verilerinde ve ameliyat sürelerinde istatistiksel olarak anlamlı bir fark yoktu. Blok noktasına ulaşma süresi, iğne derinliği ve blok başlama süresi grup l'de grup S'ye göre anlamlı derecede daha uzun bulundu (hepsi için; $p<0,001)$. Gruplar arasında motor blok süresi, duysal blok süresi ve ameliyat sonrası ilk ağıı bașlama süresi bakımından anlamlı bir fark bulunmadı.

Sonuç: Çalışmamızda supraklaviküler bloğun infraklaviküler bloğa göre blok noktasına ulașma süresi, iğne derinliği ve blok başlama süresi açısından daha avantajlı olduğunu tespit ettik.

Anahtar Kelimeler: Brakiyal pleksus bloğu, infraklaviküler, rejyonal anestezi, supraklaviküler 


\section{Introduction}

There are important advantages of regional anesthesia, including (a) the patient being conscious during the surgery, (b) spontaneous breathing of the patient, (c) maintaining airway reflexes, (d) analgesia in the postoperative period and (e) early mobilization of the patient (1).

Different regional anesthesia methods may be preferred to general anesthesia in upper extremity surgery $(2,3)$. The economic and environmental approach in daily anesthesia practice as in all areas of life has been accepted by almost all of our colleagues and therefore regional anesthesia methods have been increasingly preferred for appropriate surgeries in recent years. Having an advantage of avoiding possible complications due to general anesthesia increases the frequency of use of regional anesthesia (4).

Upper extremity blocks are more common than lower extremity blocks. The brachial plexus can be blocked by interscalene, supraclavicular, infraclavicular and axillary approaches. The brachial plexus is formed by anterior primary rami of the nerves from C5 to T1. Each of these nerves exits the intervertebral foramina and extends anterolaterally and caudally. This structure, which extends in 3 trunks in the interscalen region, is divided into lateral, medial, and posterior branches, and forms 5 peripheral nerves. Because the brachial plexus is more compact in the upper levels, it is easier to block, and therefore supraclavicular and infraclavicular approaches are used more frequently $(1,2,5)$.

Supraclavicular brachial plexus block is a popular technique for surgeries below shoulder level due to rapid onset of action and high success rate. However, complications such as vascular injection, pneumothorax, phrenic nerve palsy and Horner's syndrome are high. The most important advantages of the infraclavicular brachial plexus block are that it has fewer complications and that a catheter can be placed. However, the brachial plexus is located deeper in the infraclavicular region (6).

In our study, we aimed to compare the effectiveness of infraclavicular and supraclavicular brachial plexus blocks, which are similar approaches that provide anesthesia for the entire upper extremity in cases that will be operated for fracture and soft tissue pathology.

\section{Methods}

\section{Patients Selection and Block}

Following ethics committee approval (Bezm-i Alem Vakıf University Faculty of Medicine Hospital), patients who would undergo unilateral upper extremity surgery under elective conditions in the orthopedics and traumatology clinic were selected for the study. Fifty patients between the ages of 18-80 years with an "American Society of Anesthesiologists (ASA)" score of I or II were included in the study. Written consents were obtained from all patients.

Patients with neurological deficits, mental retardation, alcohol or drug addiction, local anesthetic substance allergy, coagulopathy, morbid obesity and pregnant women were not included in the study.

The patients included in the study were randomly divided into two groups as group I including 25 patients with infraclavicular brachial plexus block and group $\mathrm{S}$ including 25 patients with supraclavicular brachial plexus block.
The patients were taken to the regional anesthesia practice room inside the operating theater. Peripheral vascular access was performed with intravenous cannulae $(20 \mathrm{G}$ ) from the dorsum of the contralateral hand and balanced electrolyte solution was given at a dose of $5-7 \mathrm{~mL} / \mathrm{kg} / \mathrm{h}$. $0.03 \mathrm{mg} / \mathrm{kg}$ intravenous midazolam was administered to all patients as standart premedication.

Patients in group I underwent infraclavicular brachial plexus block with coracoid approach. The block was typically performed with the patient in the supine position. The arm was adducted and the elbow flexed with the palm in contact with the patient's belly. The coracoid process of the scapula was marked. Two cm below and two $\mathrm{cm}$ medial of the coracoid process was determined and was marked as the point of peripheral block injection (2).

Supraclavicular brachial plexus block was applied to patients in group $\mathrm{S}$. The block was typically performed with the patient in the supine position with the head turned away from the side to be blocked. The arms were coupled to the body on both sides. A $2 \mathrm{~cm}$ thick pillow was placed under the shoulder of the block side. Thus, the lung apex was removed from the intervention region (4). The head was extended to stretch the neck muscles. The mid-point of the clavicle was marked. The lateral edge of the clavicular head of the sternocleidomastoid muscle was found. The point of injection was determined as 1-1.5 cm above the mid-point of the clavicle and $1.5-2 \mathrm{~cm}$ from the lateral edge of the clavicular head of the sternocleidomastoid muscle. If this point hits the jugular vein, the entrance point was moved medially or laterally (4).

In both groups, an electrocardiogram (ECG) electrode was attached to the deltoid muscle of the arm to be blocked. Skin cleansing was performed with povidone iodine and local anesthesia was performed with 2 cc 2\% lidocaine. Multistimuplex (Pajunk, Germany) was used as nerve stimulator and $21 \mathrm{G}, 50 \mathrm{~mm}$ or $100 \mathrm{~mm}$ Stimuplex $\mathrm{A}^{\circ}$ (B. Braun Melsungen AG, Japan) needles that are custom made for plexus anesthesia were used. The cathode pole of the nerve stimulator was connected to the conductive end of the needle, and the anode pole was connected to the ECG electrode attached to the deltoid muscle. The stimulator was initially set to $1.0 \mathrm{~mA}, 2 \mathrm{~Hz}, 0.1 \mathrm{mS}$ parameters. From the marked point, $100 \mathrm{~mm}$ needle was inserted into the skin anthroposteriorly by forming a 90 degrees angle to the floor where the patient was lying in group I. Fifty $\mathrm{mm}$ needle was inserted from the marked point in group $\mathrm{S}$, and the needle was advanced caudally, slightly to medially and to dorsally. Skin, subcutaneous tissue and muscles were passed and fasciculations of the muscles innervated by the brachial plexus nerves (median nerve, ulnar nerve, radial nerve, musculocutaneous nerve) were searched. The fasciculation response of one of the nerves was obtained and it was considered as a successful localization indicator that the fasciculation was shown to continue when the current was decreased to $0.4 \mathrm{~mA}$. After the aspiration test, a total of $10 \mathrm{~mL}$ of $0.5 \%$ levobupivacaine and $10 \mathrm{~mL}$ $2 \%$ lidocaine were administered by repeating aspiration at every $5 \mathrm{~mL}$. Similarly, $10 \mathrm{~mL}$ 0.5\% levobupivacaine and $10 \mathrm{~mL} 2 \%$ lidocaine were administered by looking for another nerve. In each patient, two nerves out of median nerve, ulnar nerve, radial nerve and musculocutaneous nerve were located and $20 \mathrm{~mL}$ of local anesthetic combination was injected in each of them. 
At the end of the procedure, the time to block point and the needle depth were recorded in each patient. Five minutes after the procedure, the operation area was controlled at 5-minute intervals with pinprick test and cold-hot test. The onsets of motor and sensory block times were recorded. When the block was completed, the surgery was started. Quality of anesthesia and motor block were evaluated with the Hollmen scale (Table 1). Indications of surgery, operative time and onset of postoperative initial pain were recorded. Complications were also recorded in both groups.

\section{Statistical Analysis}

SPSS for Windows 15.0 (Statistical Package for Social Sciences Inc., Chicago, IL, USA) was used to evaluate the findings of the study. In addition to descriptive statistical methods (mean, standard deviation), Student's t-test and Mann-Whitney $U$ test was used to compare quantitative data, where appropriate. Chi-square test was used to compare qualitative data. The results were evaluated at 95\% confidence interval with a significance level of $p<0.05$.

\section{Results}

There was no statistically significant difference between the groups in terms of demographic data and operative time (Table 2). The indications for surgery are given in Table 3.

The time to block point, needle depth, onset of block time, duration of motor and sensory block, and onset of postoperative initial pain are shown in Table 4.

The time to block point, needle depth and onset of block time were significantly longer in group I compared to group $S(p<0.001$, for all).

There was no significant difference between the groups in terms of duration of motor block, duration of sensory block, and onset of postoperative initial pain.

In both groups, regional anesthesia was switched to general anesthesia in one case due to insufficient block. The rate of failed block was $4 \%$ in both groups.

In our study, none of our patients had arrhythmia, bradycardia, hypotension, cardiogenic shock, central toxicity, phrenic nerve block, pneumothorax, major vascular injury, Horners syndrome and neurological damage.

\begin{tabular}{|l|l|}
\hline \multicolumn{2}{|l|}{ Table 1. Hollmen scale } \\
\hline Quality of anesthesia & \\
\hline 0 & Full sensation with pinprick \\
\hline 1 & Weak sensation compared to other extremity \\
\hline 2 & Recognized as light touch \\
\hline 3 & Loss of sensation \\
\hline Quality of motor block & \\
\hline 0 & Normal motor function \\
\hline 1 & Weak motor function compared to before block \\
\hline 2 & Very weak motor function \\
\hline 3 & Complete loss of motor function \\
\hline
\end{tabular}

Table 2. Demographic features and operative time of the groups

\begin{tabular}{|l|l|l|l|l|l|}
\hline & Group I & \multicolumn{3}{|c|}{ Group S } & p \\
\hline Age & $40.96 \pm$ & 10.69 & $41.96 \pm$ & 15.76 & 0.794 \\
\hline Height $(\mathrm{cm})$ & $170.16 \pm$ & 8.43 & $169.48 \pm$ & 7.52 & 0.765 \\
\hline Weight $(\mathrm{kg})$ gender & $72.28 \pm$ & 11.57 & $77.88 \pm$ & 13.18 & 0.117 \\
\hline $\begin{array}{l}\text { (Female/male) } \\
\text { Operative time }\end{array}$ & $8 / 17$ & & $6 / 19$ & & 0.753 \\
\hline
\end{tabular}

Group I: infraclavicular brachial plexus block group, group S: supraclavicular brachial plexus block group (Data were given as $n$, mean \pm standard deviation)

Table 3. Indications for surgery of the patients

\begin{tabular}{|l|l|l|l|l|}
\hline Surgery & Grup I & \multicolumn{3}{l|}{ Grup S } \\
\hline & $\mathrm{n}$ & $\%$ & $\mathrm{n}$ & $\%$ \\
\hline Wrist fracture & 4 & $(16)$ & 1 & $(4)$ \\
\hline Phalanx fracture & 3 & $(12)$ & 11 & $(44)$ \\
\hline Humerus fracture & 3 & $(12)$ & 5 & $(20)$ \\
\hline Carpal tunnel syndrome & 5 & $(20)$ & 3 & $(12)$ \\
\hline Olecranon fracture & 4 & $(16)$ & 2 & $(8)$ \\
\hline Radius fracture & 6 & $(24)$ & 3 & $(12)$ \\
\hline
\end{tabular}

Group I: infraclavicular brachial plexus block group, group S: supraclavicular brachial plexus block group (Data were given as $\mathrm{n}$, percentage)

\begin{tabular}{|c|c|c|c|c|c|}
\hline \multirow[b]{2}{*}{ Time to block point (min) } & \multicolumn{2}{|l|}{ Grup I } & \multicolumn{2}{|l|}{ Grup S } & \multirow{2}{*}{$\begin{array}{l}\mathbf{p} \\
<0.001\end{array}$} \\
\hline & $6.36 \pm$ & 4.18 & $2.52 \pm$ & 2.62 & \\
\hline Needle depth $(\mathrm{cm})$ & $4.74 \pm$ & 0.90 & $2.49 \pm$ & 0.41 & $<0.001$ \\
\hline
\end{tabular}

Group I: infraclavicular brachial plexus block group, group S: supraclavicular brachial plexus block group (Data were given as $\mathrm{n}$, mean \pm standard deviation), min: minimum 


\section{Discussion}

The advantage of avoiding possible complications due to general anesthesia increases the frequency of application of regional anesthesia. It should be remembered that along with the problems that will be caused by the use of multiple drugs, which are mandatory for general anesthesia applications, we could protect the world we live in from fluoride gas wastes to be discharged into the atmosphere (4).

If adequate analgesia and optimum surgical conditions are achieved, performing any intervention under regional anesthesia is considered to be a more reliable method than general anesthesia (5).

Schulz-Stubner (7) argue that brachial plexus block is an effective and safe method for anesthesia or analgesia in hand and upper extremity surgery. In our study, we similarly found that the brachial plexus block was safe and effective with both approaches.

Considering the fact that an important part of hand surgery interventions are constituted by urgent and satiated patients, it is possible to avoid the side effects of general anesthesia by applying brachial plexus block to these patients.

In a study of Hadzic et al. (8), general anesthesia and infraclavicular block were compared in outpatient hand surgery attempts, and it was found that analgesia score was better with infraclavicular block, that there was no need for additional analgesia, and that it provided earlier ambulation and it was superior in terms of adverse effects.

Rodriguez et al. (9) suggested that two-nerve injection technique increased the success rate in infraclavicular brachial plexus block. In their study with 60 patients, they found that double injection using nerve stimulator was more successful than single injection. In our study, we used double injection in both infraclavicular and supraclavicular technique.

Pneumothorax may occur at a rate of 0.6 to $5 \%$ in the supraclavicular block (10). Horner syndrome, phrenic nerve block and hematoma due to injury of the major vessels can also be seen. Reversible diaphragmatic paresis of the intervened side at a rate of $28 \%$ to $80 \%$ can be seen with this technique $(10,11)$. For these reasons, the application of supraclavicular technique may cause various disadvantages especially in outpatients (10-12). None of our patients developed respiratory distress during and after surgery. Horner's syndrome, pneumothorax, nerve damage and hematoma were not seen in any of our patients.

In a study conducted in 48 volunteer men and women, Neuburger et al. (13) measured the distance of the block needle to the pleura with magnetic resonance imaging in vertical infraclavicular block and found a mean of $5.3 \mathrm{~cm}(3.1-8.7 \mathrm{~cm})$. Therefore, they showed that the infraclavicular technique is reliable against the risk of pneumothorax. In our study, the mean of needle depth was $4.74 \mathrm{~cm}$ in the infraclavicular group and $2.49 \mathrm{~cm}$ in the supraclavicular group. Although none of our patients developed respiratory distress, the possibility of pneumothorax development was considered and the chest radiographs were obtained at the $6^{\text {th }}$ hour postoperatively. No pneumothorax was observed in any of our patients.
Cox et al. (14) reported a significant reduction in the incidence of systemic toxicity with local anesthetics from $0.2 \%$ to $0.01 \%$ over the last thirty years. In addition, they stated that although the incidence of systemic toxicity in peripheral nerve blocks was highest with 7.5 per ten thousand, the neural damage rate was lowest with 1.9 per ten thousand. None of our patients developed systemic toxicity and neural damage.

De Jose Maria B et al. (15) performed a study in 80 children, aged between 5 and 15 years, and compared supraclavicular and infraclavicular brachial plexus block. Similar to our study, he found that the supraclavicular technique was performed in a shorter time and could be preferred to infraclavicular technique.

\section{Conclusion}

Brachial plexus block with infraclavicular and supraclavicular approach is safe and effective in upper extremity surgery. In our study, we found that the supraclavicular block is more advantageous in terms of time to block point, needle depth, and onset of block time.

Ethics Committee Approval: The approval was obtained from Bezm-i Alem Vakıf University Faculty of Medicine Hospital.

Informed Consent: Written consents were obtained from all patients.

Peer-review: Externally peer-reviewed.

Author Contributions: Concept - A.G.F., M.T.A.; Design - A.G.F., M.T.A.; Supervision - A.G.F., M.T.A.; Resources - A.G.F., M.T.A.; Materials - A.G.F., M.T.A.; Data Collection and/or Processing - A.G.F., M.T.A.; Analysis and/or Interpretation - A.G.F., M.T.A.; Literature Search - A.G.F., M.T.A.; Writing Manuscript - A.G.F., M.T.A.; Critical Review - A.G.F., M.T.A.

Conflict of Interest: No conflict of interest was declared by the authors.

Financial Disclosure: The authors declared that this study received no financial support.

\section{References}

1. Erdine S. Rejyonal Anestezi. Nobel Tıp Kitabevleri, İstanbul 2005: 7-33, 83-5, 93-5.

2. Şahin Ș. Santral ve periferik sinir blokları el kitabı. Rejyonal Anestezi Derneği, İstanbul 2004: 1-2: 112-7.

3. Esener Z. Klinik Anestezi. Logos Yayıncılık Tic. A.Ș., İstanbul 1997: 439: 441452.

4. Işık G. Rejyonel Anestezi. Supraklaviküler blok http://med.c.edu.tr/anestezi/ rejbrakial.htm 2002

5. Erdine S. Sinir Blokları. Emre Matbaacılık, İstanbul 1993: 49-80, 109-128.

6. Abhinaya RJ, Venkatraman R, Matheswaran P, Sivarajan G. A randomised comparative evaluation of supraclavikular and infraclavicular approaches to brachial plexus block for upper limb surgeries using both ultrasound and nerve stimulator. Indian J Anaesth 2017; 61: 581-6.

7. Schulz-Stubner S. Brachial plexus. Anesthesia and Analgesia 2003; 52: 643-56

8. Hadzic A, Arliss J, Kerimoglu B. A comparison of infraclavicular nerve block versus general anesthesia for hand and wrist daycase surgeries Anesthesiology 2004; 101: 127-32.

9. Rodriguez J, Barcena M, Lagunilla J, Alvarez J. İncreased success rate with infraclavicular brachial plexus block using a dual-injection technique. J Clin Anesth. 2004; 16: 251-6. 
10. Krafft P, Eibenberger K, Fitzgerald R. Ultrasound guided supraclavicular approach for regional anesthesia of the brachial plexus. Anesth Analg 1994; 78: 507-13.

11. Korbon GA, Carron H, Lander CJ. First rib palpation: A safer, easier technique for supraclavicular brachial plexus block. Anesth Analg 1989; 68: 682-5.

12. Bridenbaugh LD. The upper extremity: Neural Blockade. JB Lippincott, Philadelphia 1988: 393-7.
13. Neuburger M, Kaiser H, Uhl M. Biometric data on risk of pneumothorax from vertical infraclavicular brachial plexus block. A magnetic resonance imaging study. Anaesthesist 2001; 50: 511-6.

14. Cox B, Durieux ME, Marcus MA. Toxicity of local anaesthetics . Best Pract Res Clin Anaesthesiol 2003; 17: 111-36.

15. De Jose Maria B, Banus E, Navarro Egea M, Serrano S, Perello M, Mabrok M. Ultrasound-guided supraclavicular vs infraclavicular brachial plexus blocks in children. Paediatr Anaesth 2008; 18: 838-44. 